\title{
Faktor Risiko Eksternal terhadap Keterlambatan Motorik Kasar pada Anak Usia 6-24 Bulan: Studi Kasus-Kontrol
}

\author{
Kristian Kurniawan, ${ }^{*}$ Irawan Mangunatmadja** \\ *Program Studi Pendidikan Dokter** Departemen Ilmu Kesehatan Anak Fakultas Kedokteran Universitas Indonesia, Jakarta
}

\begin{abstract}
Latar belakang. Keterlambatan perkembangan merupakan kondisi ketidakmampuan anak mencapai milestone perkembangan seusianya. Perkembangan motorik kasar dapat memprediksi tingkat maturasi sistem saraf pusat fungsional sehingga keterlambatan pada domain ini akan berdampak pada keterlambatan penguasaan domain perkembangan lainnya.

Tujuan. Mengidentifikasi faktor risiko eksternal terhadap keterlambatan motorik kasar pada anak 6-24 bulan.

Metode. Penelitian dilakukan dengan metode kasus-kontrol pada populasi anak usia 6-24 bulan menggunakan data primer yang diperoleh di RSUPN Cipto Mangunkusumo Kiara, Jakarta Pusat dan Klinik Anakku, Jakarta Selatan.

Hasil. Diperoleh subjek sebesar 128 anak, dengan perbandingan kasus-kontrol 1:1 pada kelompok rentang usia yang sesuai. Dari hasil analisis pearson kai-kuardat diperoleh 2 faktor signifikan terhadap keterlambatan motorik kasar, yakni: status gizi kurang/buruk $(\mathrm{p}<0,001 ; \mathrm{OR}=6,576$; IK 95\%=2,705-13,986) dan tidak diberikannya ASI eksklusif $(\mathrm{p}=0,032 ; \mathrm{OR}=2,180 ; \mathrm{IK} 95 \%=1,065-4,460)$. Di sisi lain, faktor urutan anak, usia ibu saat kehamilan, dan cara kelahiran menunjukkan hasil tidak bermakna terhadap keterlambatan motorik kasar. Kemudian, dari analisis multivariat dengan regresi logistik biner, menunjukkan bahwa status gizi kurang/buruk merupakan faktor paling berpengaruh terhadap kejadian keterlambatan motorik kasar pada anak ( $<<0,001 ;$ OR =6, 159; IK 95\%=2,51215,099).
\end{abstract}

Kesimpulan. Status gizi kurang/buruk merupakan faktor prediktor keterlambatan motorik kasar yang paling berpengaruh. Sari Pediatri 2019;21(1):24-30

Kata kunci: keterlambatan motorik kasar, anak, faktor risiko, status gizi, ASI eksklusif

\section{External Risk Factors for Gross Motor Delay in Children Aged 6-24 Months Old: A Case-Control Study}

Kristian Kurniawan, Irawan Mangunatmadja

Background. Developmental delay is a condition which child fails to achieve appropriate developmental milestone according to his age. Gross motor development could predict certain functional central nervous system maturation, thus delay in this domain might inhibit mastering process of other domains.

Objectives To determine significant external risk factors for gross motor delay in children aged 6-24 months.

Method. This study was conducted with case-control approach on children aged 6-24 months old using primary data obtained from RSUPN Cipto Mangunkusumo Kiara, Central Jakarta and in Klinik Anakku, South Jakarta.

Results. A total of 128 pediatric patients were found to be subjected, with case-control ratio 1:1 in corresponding age group range. According to Pearson chi-square test, there are two significant factors for gross motor delay, which are wasting/severely wasting $(\mathrm{p}<0,001 ; \mathrm{OR}=6,576$; CI 95\%=2,705-13,986) and not exclusively breastfeeding ( $\mathrm{p}=0,032 ; \mathrm{OR}=2,180 ; \mathrm{CI} 95 \%=1,065-4,460)$. On the other hand, birth order, maternal age during gestation, and mode of delivery demonstrate insignificant result for gross motor delay. Furthermore, multivariate analysis with binary logistic regression shows that wasting/severely wasting to be the most influential external risk factor for gross motor delay ( $\mathrm{p}<0,001$; OR=6,159; CI 95\%=2,512-15,099).

Conclusion. Wasting/severely wasting is proven to be the most influential predictor factor for gross motor delay. Sari Pediatri 2019;21(1):24-30

Keywords: gross motor delay, risk factors, children, nutritional status, exclusive breastfeeding

Alamat korespondensi: Irawan Mangunatmadja. Departemen Ilmu Kesehatan Anak Fakultas Kedokteran Universitas Indonesia. Jl. Salemba Raya, no. 6, Jakarta Pusat, 10430. Telpon: 0813-1457-8483 Email: irawanma12@yahoo.com 
$\mathrm{K}$ eterlambatan perkembangan merupakan suatu kondisi yang mana seorang anak mengalami keterlambatan dalam meraih kanak awal.1 Masalah perkembangan sudah menjadi masalah umum dalam berbagai kategori masalah dalam bidang pediatrik. Pada 2008, 15\% anak usia 3-7 tahun mengalami disabilitas perkembangan dan $25 \%$ anak mengalami masalah psikososial.2 Dari hasil penelitian Granhatam-McGregor3 yang dipublikasi di Lancet, diestimasikan secara global bahwa lebih dari 200 juta anak di bawah usia 5 tahun di negara berkembang tidak mencapai potensi perkembangan secara penuh.

Perkembangan anak ditandai dengan kemajuan perkembangan pada berbagai domain perkembangan, seperti kemampuan motorik kasar, motorik halus, sosial, emosional, bahasa, dan pengetahuan. Dari seluruh kategori, domain motorik kasar merupakan domain dasar perkembangan seorang anak sebelum menjajaki domain lainnya. ${ }^{4}$ Perkembangan motorik kasar mengikuti suatu sekuens terprediksi, yang memprediksikan tingkat maturasi sistem saraf pusat fungsional. ${ }^{5}$ Oleh karena itu, terjadinya keterlambatan perkembangan motorik kasar akan berdampak pada keterlambatan penguasaan domain perkembangan lainnya.

Banyak studi penelitian telah menyatakan kemungkinan faktor yang memiliki korelasi terhadap keterlambatan motorik secara umum. Akan tetapi, faktor risiko yang dispesifikan terhadap keterlambatan motorik kasar belum pernah dilakukan sebelumnya. ${ }^{6-8}$ Penilaian perkembangan dilakukan pada serial waktu tertentu sesuai alat skrining terstandardisasi, disertai dengan pendekatan evaluatif. ${ }^{9,10}$

Penelitian ini bertujuan meneliti faktor risiko eksternal terhadap keterlambatan motorik kasar pada anak usia 6-24 bulan. Rentang usia 6-24 bulan dipilih berdasarkan pertimbangan bahwa masa perkembangan neuronal pada anak terjadi paling pesat hingga usia 3 tahun. ${ }^{4}$

\section{Metode}

Penelitian ini menggunakan metode case-control untuk mengetahui faktor risiko terkait keterlambatan motorik kasar pada anak. Pendekatan observasional ini dipilih atas dasar kesesuaian desain untuk penelitian klinis serta untuk mencari faktor risiko terkait dengan cara membandingkan antara kelompok kasus dengan kelompok kontrol. Kelompok kasus merupakan anak dengan keterlambatan motorik kasar, mengacu pada "Pola Penyaringan untuk Keterlambatan Perkembangan: Rentang Atas", sedangkan kelompok kontrol merupakan anak dengan perkembangan motorik normal. ${ }^{11}$

Data primer digunakan berdasarkan penilaian terhadap keterampilan motorik kasar secara langsung yang kemudian dikonfirmasi oleh dokter spesialis anak; pengambilan informasi terkait faktor risiko yang diteliti diperoleh dari orang tua pasien ataupun pengukuran pada anak dalam hal status gizi. Dilakukan pula match usia dalam rentang umur tertentu antara kasus dengan kontrol. Sebagai contoh, jika terdapat 10 anak pada kasus anak usia 6-9 tahun, diperlukan 10 anak pada kontrol anak usia 6-9 tahun. Hal ini ditunjukan untuk memeroleh hasil pembanding yang representatif sesuai kelompok rentang umur.

Kriteria inklusi mencakup seluruh anak usia 6-4 bulan tepat saat pengambilan data dilakukan, dan orang tua kandung/wali menyetujui informed consent secara tertulis. Di samping itu, kriteria eksklusi mencakup anak dengan kelainan kongenital, seperti hidrosegalus, sindrom Down, sindrom Otahara, dan sindrom lainnya. Anak dengan gangguan yang menghambat gerak motorik, seperti fraktur, gangguan neurologis, atrofi, dan gangguan lainnya juga dieksklusikan.

Penelitian dilakukan pada anak usia 6-24 bulan di Poliklinik Anak Rumah Sakit Umum Pusat Nasional Cipto Mangunkusumo Kiara, Jakarta Pusat, Indonesia dan Klinik Anakku, Pondok Indah, Jakarta Selatan, Indonesia. Penelitian dilakukan dalam enam bulan, yaitu bulan Maret - Agustus 2018.

Data primer digunakan sebagai sumber data. Informasi mengenai faktor risiko diambil dengan cara pengukuran pada pasien dan wawancara orangtua pasien secara langsung. Data primer yang diperoleh kemudian diperiksa kembali kelengkapannya, lalu data dikoding sesuai variabel sesuai batasan operasional.

Pertama, data diolah secara univariat untuk memberikan gambaran karakteristik umum populasi sampel. Kedua, semua variabel terkait dianalisis secara bivariat dengan menggunakan analisis Pearson kaikuardat. Terakhir, pada variabel yang bermakna dari hasil analisis bivariat, kemudian akan dilakukan analisis multivariat dengan regresi logistik. Proses ini dilakukan dengan menggunakan program SPSS versi 20.0. 


\section{Hasil}

Dalam kurun waktu penelitian diperoleh jumlah total sampel penelitian 138 anak, mencakup 65 anak dengan keterlambatan motorik kasar (kasus) dan 73 anak dengan perkembangan motorik kasar normal (kontrol). Semua subjek berada dalam rentang umur 6-24 bulan. Mengacu pada metode yang digunakan dengan membandingkan kelompok kasus dengan kontrol dalam rentang usia yang bersesuaian, digunakanlah sampel sejumlah 128 anak dengan perbandingan kasus banding kontrol 1:1. Distribusi subjek penelitian berdasarkan karakteristik umum subjek per kelompok kasus, seperti: gender, kelompok usia, dan pendidikan orang tua, secara menyeluruh tertera pada Tabel 1.

Hubungan asosiasi analisis bivariat antara pajanan variabel bebas pada kelompok kasus dengan kelompok kontrol dengan uji hipotesis non-parametrik berupa uji Pearson kai-kuadrat $\left(\mathrm{X}^{2}\right)$ untuk menilai signifikansi setiap variabel. Setelah itu dilakukan perhitungan $O d d s$ ratio pada setiap variabel dengan rumus $a d / b c$ mengacu pada pola tabel $2 \times 2$. Variabel bebas merupakan faktor eksternal (dipengaruhi dari luar), meliputi status gizi anak, urutan anak, usia ibu saat mengandung, ASI eksklusif, dan peroses persalinan. Hasil analisis bivariat dapat tertera pada Tabel 2.

Berdasarkan hasil analisis bivariat tersebut terdapat dua buah faktor yang menunjukkan hubungan signifikan bermakna, yakni status gizi kurang/ buruk ( $<<0,001 ; \mathrm{OR}=6,576$; IK95\%=2,705-13,986) dan tidak memberikan ASI eksklusif ( $\mathrm{p}=0,032$; $\mathrm{OR}=2,180$; IK95\%=1,065-4,460). Di sisi lain, faktor lainnya menunjukkan hasil tidak signifikan dengan nilai $p \geq 0,05$, seperti urutan anak $(p=0,694)$, umur ibu ketika hamil $(\mathrm{p}=0,840)$, dan proses persalinan $(\mathrm{p}=0,860)$.

Analisis multivariat dilakukan dengan regresi logistik biner, dalam bentuk logistik regresi backward stepwise untuk mengeksklusi data yang tidak signifikan. Variabel bebas yang dimasukkan ke dalam analisis mulitvariat merupakan variabel yang signifikan pada analisis bivariat memiliki nilai $\mathrm{p}<0,05$ dan $\mathrm{OR}>1$ serta dimasukkan pula variabel bebas lainnya dengan nilai $\mathrm{p}<0,25$ pada analisis bivariat. Terdapat dua variabel bebas yang masuk ke dalam analisis, yaitu variabel status gizi anak dan ASI eksklusif. Hasil analisis multivariat dengan regresi logistik biner tertera pada Tabel 3 .

Tabel 1. Karakteristik umum subjek penelitian $(\mathrm{n}=128)$

\begin{tabular}{lcccccc}
\hline Variabel & $\begin{array}{c}\text { Perkembangan motorik kasar } \\
\text { terlambat (kasus) } \\
(\mathrm{n}=64)\end{array}$ & $\begin{array}{c}\text { Perkembangan motorik kasar } \\
\text { normal (kontrol) } \\
(\mathrm{n}=64)\end{array}$ & \multicolumn{2}{c}{$\begin{array}{c}\text { Total } \\
(\mathrm{n}=128)\end{array}$} \\
\cline { 2 - 7 } & $\mathrm{N}$ & $(\%)$ & $\mathrm{N}$ & $(\%)$ & $\mathrm{N}$ & $(\%)$ \\
\hline Gender & & & & & & \\
$\quad$ Laki-laki & 40 & 62,5 & 37 & 57,8 & 77 & 60,2 \\
$\quad$ Perempuan & 24 & 37,5 & 27 & 42,2 & 51 & 39,8 \\
\hline Usia (bulan) & & & & & & \\
6-9 & 12 & 18,8 & 12 & 18,8 & 24 & 18,8 \\
10-12 & 10 & 15,8 & 10 & 15,8 & 20 & 15,8 \\
13-15 & 5 & 7,8 & 5 & 7,8 & 10 & 7,8 \\
16-18 & 10 & 15,6 & 10 & 15,6 & 20 & 15,6 \\
19-21 & 13 & 20,3 & 13 & 20,3 & 26 & 20,3 \\
22-24 & 14 & 21,9 & 14 & 21,9 & 28 & 21,9 \\
Pendidikan ibu & & & & & & \\
SD-SMP & 16 & 25,0 & 17 & 26,6 & 33 & 25,8 \\
SMA-Sarjana & 46 & 71,9 & 45 & 70,3 & 91 & 71,1 \\
Tidak menjawab & 2 & 3,1 & 2 & 3,1 & 4 & 3,1 \\
Pendidikan ayah & & & & & & \\
$\quad$ SD-SMP & 16 & 25,0 & 14 & 21,9 & 30 & 23,4 \\
SMA-Sarjana & 46 & 71,9 & 47 & 73,4 & 93 & 72,7 \\
Tidak menjawab & 2 & 3,1 & 3 & 4,7 & 5 & 3,9 \\
\hline
\end{tabular}


Kristian Kurniawan dkk: Faktor risiko eksternal terhadap keterlambatan motorik kasar anak usia 6-24 bulan: studi kasus-kontrol

Tabel 2. Analisis bivariat faktor eksternal terhadap keterlambatan motorik kasar

\begin{tabular}{|c|c|c|c|c|c|}
\hline Variabel & $\begin{array}{c}\text { Motorik kasar terlambat } \\
\text { (kasus) } \\
(\mathrm{n}=64)\end{array}$ & $\begin{array}{l}\text { Motorik kasar normal } \\
\quad(\text { kontrol) } \\
(\mathrm{n}=64)\end{array}$ & Nilai-p & OR & IK95\% \\
\hline \multicolumn{6}{|l|}{ Status gizi anak } \\
\hline Kurang/buruk & 31 & 8 & $<0,001^{*}$ & 6,576 & $2,705-13,986$ \\
\hline Baik & 33 & 56 & & & \\
\hline \multicolumn{6}{|l|}{ Urutan anak } \\
\hline $\mathrm{Ke}-\geq 2$ & 45 & 47 & 0,694 & 0,857 & $0,396-1,853$ \\
\hline Pertama & 19 & 17 & & & \\
\hline \multicolumn{6}{|l|}{ Usia ibu ketika hamil } \\
\hline$\leq 19$ atau $\geq 35$ tahun & 16 & 17 & 0,840 & 0,922 & $0,417-2,035$ \\
\hline 20-35 tahun & 48 & 47 & & & \\
\hline \multicolumn{6}{|l|}{ ASI eksklusif } \\
\hline Tidak & 33 & 21 & $0,032^{*}$ & 2,180 & $1,065-4,460$ \\
\hline $\mathrm{Ya}$ & 31 & 43 & & & \\
\hline \multicolumn{6}{|l|}{ Proses persalinan } \\
\hline Cesar & 31 & 30 & 0,860 & 1,065 & $0,532-2,131$ \\
\hline Normal & 33 & 34 & & & \\
\hline
\end{tabular}

*Signifikan $=\mathrm{p}<0,05$

Tabel 3. Analisis multivariat faktor eksternal terhadap keterlambatan motorik kasar (final model)

\begin{tabular}{lccccc}
\hline Variabel & $\mathrm{B}$ & $\mathrm{SE}$ & Nilai-p & OR & IK95\% \\
\hline Status gizi anak (kurang/buruk) & 1,818 & 0,458 & $0,001^{*}$ & 6,159 & $2,512-15,099$ \\
ASI eksklusif (tidak diberi) & 0,629 & 0,394 & 0,110 & 1,876 & $0,867-4,063$ \\
Konstan & $-1,674$ & 0,455 & 0,001 & 0,187 & \\
\hline
\end{tabular}

*Signifikan $=\mathrm{p}<0,05$

Hasil analisis multivariat tahap 1 menunjukkan bahwa status gizi kurang/buruk anak signifikan terhadap terjadinya keterlambatan motorik kasar dengan nilai $\mathrm{p}<0,001(\mathrm{OR}=6,159$; IK95\%=2,51215,099). Di sisi lain, faktor tidak diberikan ASI eksklusif ( $\mathrm{p}=0,110$; OR=1,876; IK95\%=0,867-4,063) tidak signifikan sebagai faktor prediktor eksternal terhadap kejadian keterlambatan motorik kasar pada anak usia 6-24 bulan secara multivariat.

Dari hasil analisis multivariat, ditunjukan bahwa status gizi kurang/buruk pada anak merupakan faktor eksternal yang berpengaruh paling kuat terhadap kejadian keterlambatan motorik kasar pada anak 6-24 bulan. Di sisi lain, tidak diberikannya ASI eksklusif menjadi tidak signifikan terhadap keterlambatan motorik kasar dalam setting multivariat.

\section{Pembahasan}

Dalam penelitian ini, peneliti menginvestigasi faktorfaktor eksternal yang diyakini sebagai faktor risiko terhadap keterlambatan motorik kasar pada anak. Status gizi anak, urutan anak, usia ibu saat hamil, ASI eksklusif, dan proses persalinan diteliti sebagai faktor eksternal . Berdasarkan hasil analisis observasi kami menemukan bahwa keterlambatan motorik kasar pada anak usia 6-24 bulan menunjukkan hubungan bermakna dengan faktor status gizi anak kurang/buruk dan tidak dilakukannya ASI eksklusif. Sementara untuk faktor eksternal lainnya, kami tidak menemukan kebermaknaan, seperti urutan anak, umur ibu ketika hamil, dan proses persalinan.

Status gizi anak kurang/buruk dinyatakan 
berdasarkan hasil pengukuran $\mathrm{BB} / \mathrm{TB}$ menggunakan kurva WHO untuk anak di bawah sama dengan 2 tahun, dengan hasil intepretasi interseksi dara pada area $<-2$ SD. Ditemukan 48,4\% anak berstatus gizi kurang/buruk dari 64 anak dengan keterlambatan motorik kasar (kasus),. Setelah dilakukan uji analisis bivariat, faktor ini terbukti menjadi variabel yang bermakna terhadap terjadinya keterlambatan motorik kasar pada anak.

Hasil tersebut sejalan dengan laporan penelitian kasus-kontrol Arumsari $\mathrm{dkk}^{6}$ yang menelaah hubungan antara status gizi dengan perkembangan secara global. Arumsari melaporkan bahwa status gizi anak kurang/buruk terbukti merupakan faktor yang bermakna terhadap keterlambatan motorik global pada anak. Selain itu, ditekankan pula bahwa status gizi memiliki peran penting terhadap tumbuh kembang anak, terutama dalam menunjang perkembangan sistem saraf pusat ataupun perifer. Dengan kata lain, anak dengan status gizi kurang/buruk memiliki risiko lebih besar mengalami keterlambatan perkembangan di berbagai domain.

Ali ${ }^{12}$ melaporkan bahwa status gizi yang buruk merupakan suatu faktor negatif bagi perkembangan sistem saraf pusat. Di samping itu ditekankan pula bahwa, status gizi kurang/buruk berdampak pula pada sistem imun seorang anak yang makin memburuk sehingga rentan terhadap infeksi. Dalam kondisi infeksi, kebutuhan kalori pun meningkat untuk mempertahankan sistem pertahanan tubuh. Dengan kata lain, kondisi ini dapat membentuk siklus ganas yang menghisap banyak kebutuhan nutrisi sehingga status gizi kian memburuk dan meningkatkan dampak negatif terhadap tumbuh kembang anak.

Beberapa studi lain mendukung faktor status gizi memperkuat peran penting terhadap perkembangan motorik. Sachdeva $\mathrm{dkk}^{13}$ melaporkan bahwa faktor nutrisi berupa defisiensi energi kronik dapat bermanifestasi terhadap terhambatnya tumbuh kembang sesuai dengan usianya. Masloman $\mathrm{dkk},{ }^{14}$ melaporkan keterlambatan perkembangan pada anak dengan malnutrisi ringan-sedang, seorang anak usia 8 bulan tidak mampu duduk tanpa sokongan. . Sebagaimana diketahui bahwa kemampuan sesorang anak untuk duduk tanpa sokongan seharusnya sudah tercapai pada usia 6 bulan mengacu milestone perkembangan motorik kasar. ${ }^{11}$

Sebagai tambahan, mengacu pada kajian oleh Prado $\mathrm{dkk}^{15}$ mengenai nutrisi dan perkembangan otak di awal kehidupan, terdapat beberapa hal yang direkomendasikan untuk mencegah serta memperbaiki kondisi status gizi kurang/buruk. Pertama, pemberian ASI eksklusif selama 6 bulan pertama kehidupan dan dilanjut dengan pemberian MPASI (makanan pendamping air susu ibu) yang adekuat dengan kombinasi pemberian ASI berkelanjutan. Kedua, pemenuhan makro dan mikro nutrien dari masa kehamilan hingga masa kanak (1000 hari pertama kehidupan). Pemenuhan nutrien tersebut mencakup suplementasi berupa zat besi, asam folat, asam lemak esensial, hingga MPASI yang difortifikasi. Dengan memperbaiki dan meningkatkan status gizi anak pada 1000 hari kehidupan maka perkembangan otak dicapai secara penuh dan dapat mencegah terjadinya keterlambatan perkembangan.

Mengacu pada rekomendasi WHO, ASI eksklusif didefinisikan sebagai pemberian ASI secara khusus kepada anak selama 6 bulan pertama kehidupan sebagai asupan nutrisi utama. ${ }^{16} \mathrm{Kami}$ menemukan 51,6\% anak di antara kelompok kasus memiliki riwayat ASI non eksklusif. Berdasarkan hasil analisis bivariat diperoleh bahwa pemberian ASI non eksklusif merupakan faktor bermakna terhadap kejadian keterlambatan motorik kasar.

Hasil penelitian ini bersesuaian dengan hasil penelitian yang dilakukan oleh $\mathrm{Hikmah}^{7}$ yang melaporkan bahwa anak dengan keterlambatan perkembangan memiliki Odds 3,3 kali pemberian ASI non eksklusif. Dalam pembahasannya ditegaskan bahwa, pemberian ASI eksklusif selama 6 bulan pertama dapat membantu pencapaian perkembangan anak secara optimal. Hal ini sejalan dengan hasil penelitian yang melaporkan bahwa proporsi anak yang diberikan ASI eksklusif memiliki perkembangan yang lebih baik.

Studi lain terkait hubungan antara pemberian ASI dengan keterlambatan perkembangan melaporkan hasil yang kohesif. Halpern $\mathrm{dkk}^{17}$ melaporkan bahwa terdapat keterkaitan antara pemberian ASI dengan keterlambatan perkembangan yang dinilai dengan tes Denver II. Hasil penelitian tersebut menggambarkan spektrum bahwa pada kelompok dengan keterlambatan perkembangan, rasio Odds akan semakin tinggi sejalan dengan tingkat pemberian ASI yang semakin rendah. Sesuai definisi, kedua variabel pada penelitian tersebut tercakup ke dalam kategori pemberian ASI non eksklusif.

Pemberian ASI memberikan banyak keuntungan bagi anak dari berbagai aspek yang ada. Air susu 
ibumemiliki kandungan semua nutrien esensial yang diperlukan bayi dalam 6 bulan kehidupan pertamanya. Sebagaimana diketahui, ASI mengandung IgA yang merupakan antibodi sebagai imunitas pasif dari ibu bagi sang buah hati. Dengan kata lain, pemberian ASI dapat mencegah anak dari infeksi, seperti pada diare dan pneumonia. ${ }^{16}$ Bersesuaian dengan laporan studi $\mathrm{Ali}^{12}$ yang telah dipaparkan di atas. Kondisi infeksi akan meningkatkan penggunaan kalori dan nutrien tubuh untuk melawan infeksi. Dapat disimpulkan, pemberian ASI secara tidak langsung mencegah terjadinya infeksi yang dapat menyebabkan pengurangan nutrien tubuh yang berdampak pada status gizi. Lebih lanjut, kandungan gizi pada ASI dapat meningkatkan kebutuhan nutrisi sang anak untuk mencapai status gizi baik.

Selain itu, Ali, dkk ${ }^{18}$, juga melaporkan bahwa pemberian ASI eksklusif selama minimal 6 bulan secara bermakna dapat meningkatkan penilaian terhadap perkembangan motorik kasar dengan Ages and Stages Quesstionnaire (ASQ).

Analisis multivariat dilakukan dengan logistik regresi terhadap faktor yang termasuk ke dalam kriteria analisis multivariat yang mencakup status gizi dan ASI eksklusif. Setelah dilakukan analisis multivariat, faktor status gizi anak kurang/buruk merupakan faktor eksternal yang paling berpengaruh terhadap keterlambatan motorik kasar pada anak 6-24 bulan. Hasil multivariat ini sejalan dengan hasil analisis multivariat status gizi anak kurang/buruk terhadap keterlambatan perkembangan global yang dilakukan oleh Arumsari dkk. ${ }^{6}$. Selain itu terdapat studi analis multivariabel lain yang secara tidak langsung menggambarkan asupan gizi yang buruk, yakni pertumbuhan yang terhambat (stunting). Sachdeva $\mathrm{dkk}^{13}$ melaporkan bahwa pertumbuhan terhambat merupakan faktor bermakna terhadap keterlambatan perkembangan. Jika dibandingkan dalam setting multivariabel antar penelitian, status gizi kurang/buruk memiliki rasio Odds yang relatif sama terhadap keterlambatan perkembangan, tetapi pada penelitian ini variabel terikat dispesifikasikan terhadap keterlambatan motorik kasar.

Pada analisis multivariat, faktor pemberian ASI non eksklusif menunjukkan ketidakbermaknaan terhadap keterlambatan motorik kasar. Faktor pemberian ASI non eksklusif dalam analisis multivariat ini disandingkan hanya dengan faktor status gizi anak kurang/buruk. Hasil ini juga ditemukan analisis multivariat pada penelitian kasus-kontrol oleh Hikmah. ${ }^{7}$ Sebuah studi dengan level-evidence lebih tinggi berupa studi kohort oleh de Moura ${ }^{19}$ melaporkan bahwa secara multivariabel durasi pemberian ASI tidak bermakna bila bersanding dengan faktor lainnya terhadap keterlambatan perkembangan. Terdapat kemungkinan bahwa, pada setting penelitian ini, pemberian ASI eksklusif dapat memengaruhi status gizi anak sehingga perkembangan sistem saraf pusat dan motorik dapat berkembang. Oleh sebab itu, dalam model multivariabel, status gizi anak kurang/buruk menjadi faktor yang lebih kuat terhadap keterlambatan motorik kasar dibandingkan dengan faktor pemberian ASI non eksklusif.

\section{Kesimpulan}

Status gizi anak kurang/buruk dan ASI eksklusif merupakan faktor eksternal yang paling berpengaruh terhadap keterlambatan motorik kasar anak usia 6-24 bulan.

\section{Saran}

Pasien dengan faktor risiko berupa status gizi kurang/ buruk dan riwayat pemberian ASI non eksklusif perlu dipantau perkembangan motorik kasarnya. Sebaliknya, pasien dengan keterlambatan motorik kasar, status gizi harus dimonitor dengan baik.

\section{Daftar pustaka}

1. Shiel WC, Stoepller MC, Lee D, Marks JW, Mathur R, Lee C, dkk. Webster's new world: medical dictionary. Edisi ke-3. New Jersey: Wiley Publishing Inc; 2008.h.113.

2. Marcdante KJ, Kliegman RM. Nelson essentials of pediatrics. Edisi ke-7. Philadelphia: Elsevier Saunders; 2015.h.15-20.

3. Grantham-McGregor S, Yin BC, Cueto S, Glewwe P, Richter L, Strupp B, dkk. Developmental potential in the first 5 years for children in developing countries. Lancet 2007;369:60-70.

4. Kliegman RM, Stanton BF, St Geme III JW, Schor NF, Behrman RE. Nelson textbook of pediatrics. Edisi ke-20. Toronto: Elsevier; 2016.h.48-56.

5. Noritz GH, Murphy NA. Motor delays: early identification and evaluation. Pediatrics 2013;131:2016-27.

6. Arumsari DR, Faizi M. Faktor risiko yang berhubungan 
Kristian Kurniawan dkk: Faktor risiko eksternal terhadap keterlambatan motorik kasar anak usia 6-24 bulan: studi kasus-kontrol

dengan keterlambatan perkembangan global pada balita. J Unair 2013;1:28-38.

7. Hikmah K. Analisis faktor-faktor risiko perkembangan anak balita di kabupaten kudus. J Kebidanan 2016;5:1-6.

8. Pratiwi AR. Hubungan proses persalinan terhadap perkembangan motorik pada bayi usia 4 bulan dan 10 bulan. Universitas Muhammadiyah Surakarta [PDF]. Jan 2016. [dikutip pada 03 Mai 2017]. Diunduh dari: http://eprints.ums. ac.id/41786/50/fp\%20new.pdf.

9. Duby JC, Lipkin PH, Macias MM, Wegner LM, Duncan P, Hagan JF, dkk. Identifying infants and young children with developmental disorders in the medical home: an alogrithm for developmental surveillance and screening. Pediatrics 2006;118:405-20.

10. Swaiman KF, Ashwal S, Ferriero DM, Schor NF. Swaiman's pediatric neurology: principles and practice. Edisi ke-5. Beijing: Elsevier Saunder; 2012.h.33-42.

11. Lehman RK, Schor NF. The nervous system; neurologic evaluation. Dalam: Kliegman RM, Stanton BF, St Geme III JW, Schor NF, Behrman RE, penyunting. Nelson textbook of pediatrics. Edisi ke-20. Toronto: Elsevier; 2016. h. 2791802.

12. Ali SS. A brief review of risk-factors for growth and developmental delay among preschool children in developing countries. Adv Biomed Res 2013;2:1-7.

13. Sachdeva S, Amir A, Alam S, Khan Z, Khalique N, Ansari MA. Global developmental delay and its determinants among urban infants and toddlers: a cross sectional study. Indian J Pediatr 2010;77:975-80.

14. Masloman N, Gunawan S. The association between nutritional status and motor development in children under five years old. Peadiatrica Indones 2005;45:07-10.

15. Prado EL, Dewey KG. Nutrition and brain development in early life. Nut Rev 2014;72:267-84.

16. World Health Organization.Exclusive breastfeeding for optimal growth, development and health of infants. Dikutip pada 14 Okt 2017. Didapat dari: https://www.who.intlelenal titles/exclusive_breastfeeding/en/WHO.

17. Halpern R, Gingliani ERJ, Victora CG, Barros FC, Horta BL. Risk factors for suspicion of developmental delays at 12 months of age. J de Pediatria 2000;76:421-8.

18. Ali SS, Dhaded, Goudar S. The impact of nutrition on child developmment at 3 years in a rural community of India.Int J Prev Med 2014;5:494-9.

19. De Moura DR, Costa JC, Santos IS, Barros AJD, Matijasevich, Halpern R, dkk. Risk factors for suspected developmental delay at age 2 years in a Brazilian birth cohort. Pediatr Pernat Epidemiol 2010;24:211-21. 